\title{
LAJU AKUMULASI SEDIMEN MANGROVE DI TANJUNG BATU, KEPULAUAN DERAWAN KALIMANTAN TIMUR
}

\section{MANGROVE SEDIMENT ACCUMULATION RATE IN TANJUNG BATU, KEPULAUAN DERA WAN, EAST BORNEO}

\author{
Intan Sari Dewi ${ }^{1 *}$, Tri Prartono ${ }^{2}$, Ali Arman ${ }^{3}$, \& Alan F. Koropitan ${ }^{2}$ \\ ${ }^{1}$ Program Studi Ilmu Kelautan, Sekolah Pascasarjana, IPB University, Bogor, 16680, Indonesia \\ ${ }^{2}$ Departemen Ilmu dan Teknologi Kelautan, FPIK, IPB University, Bogor, 16680, Indonesia \\ ${ }^{3}$ Pusat Aplikasi Isotop dan Radiasi, Badan Tenaga Nuklir Nasional, Jakarta, 12240, Indonesia \\ *E-mail: intansaridewi28@gmail.com
}

\begin{abstract}
The sustainability of mangrove ecosystems is an important aspect because it is related to the decreasing or addition of sediment accumulation such as abrasion and accretion processes. Mangroves in Tanjung Batu have decreased since 2001-2010 due to community activities such as logging, clearing land for ponds and oil palm plantations. This study aims to estimate of mangrove sediment accumulation rate in Tanjung Batu. The study was conducted in February-July 2018. Sampling was carried out at 3 stations including identification of mangrove species, measurement of diameter at breast height $(D B H)$ and sediment corring used stainless pipes. Sediment samples were cut based on intervals $5 \mathrm{~cm}$ (depth 0-15 cm), and intervals $2 \mathrm{~cm}$ (depth $48-50 \mathrm{~cm}$ ) used as supported Pb-210 (Stations 1 and 3). Station 5 is cut at intervals of 4, 6 and $8 \mathrm{~cm}$ (depths 1-50 cm). Samples analysis using alpha spectrometer to determine radioisotope Pb-210. Determination of sediment age and sediment accumulation rate using the Constant Rates of Supply (CRS) model. The results showed that the rate of sediment accumulation in the last 20 years (1998-2018) ranged 0.09-0.20 $\mathrm{g} \mathrm{cm}^{-2}$ years${ }^{1}$. The highest accumulation rate at Station 1 which is location with the oldest age and mangrove density in $\mathrm{DBH}>5 \mathrm{~cm}$, while the lowest accumulation rate is at Station 5 which has the youngest sediment age and mangroves in $\mathrm{DBH}<5 \mathrm{~cm}$.
\end{abstract}

Keywords: mangrove, $P b-210$, sediments accumulation, Tanjung Batu

\begin{abstract}
ABSTRAK
Keberlangsungan ekosistem mangrove merupakan aspek penting karena berkaitan dengan pengurangan atau penambahan akumulasi sedimen seperti proses abrasi dan akresi. Mangrove di pesisir Tanjung Batu telah mengalami penurunan sejak 2001-2010 yang disebabkan oleh aktivitas masyarakat seperti penebangan pohon, pembukaan lahan untuk tambak dan perkebunan kelapa sawit. Penelitian ini bertujuan mengestimasi laju akumulasi sedimen mangrove di Tanjung Batu. Penelitian dilakukan pada bulan Februari-Juli 2018. Pengambilan sampel dilakukan pada 3 stasiun meliputi identifikasi jenis mangrove, pengukuran Diameter at Breast Height (DBH) mangrove dan pengambilan sedimen corring menggunakan pipa stainless. Sampel sedimen dipotong berdasarkan interval $5 \mathrm{~cm}$ (kedalaman 0-15 cm), dan interval $2 \mathrm{~cm}$ (kedalaman 48-50 $\mathrm{cm}$ ) yang digunakan sebagai $\mathrm{Pb}-210$ supported (Stasiun 1 dan 3). Stasiun 5 dipotong dengan interval 4, 6 dan $8 \mathrm{~cm}$ (kedalaman 1$50 \mathrm{~cm}$ ). Analisis sampel menggunakan alpha spektrometer dengan radioisotop $\mathrm{Pb}-210$. Penentuan umur sedimen dan laju akumulasi sedimen menggunakan model Constant Rates of Supply (CRS). Hasil menunjukkan bahwa laju akumulasi sedimen selama 20 tahun terakhir (1998-2018) berkisar 0,09-0,20 $\mathrm{g} \mathrm{cm}^{-2} \operatorname{tahun}^{-1}$. Laju akumulasi tertinggi adalah Stasiun 1 yang merupakan lokasi dengan umur sedimen paling tua dan didominasi mangrove dengan DBH $>5 \mathrm{~cm}$, sedangkan laju akumulasi terendah adalah Stasiun 5 yang memiliki umur sedimen paling muda dan didominasi mangrove dengan $\mathrm{DBH}<5 \mathrm{~cm}$.
\end{abstract}

Kata kunci: akumulasi sedimen, mangrove, $\mathrm{Pb}-210$, Tanjung Batu 


\section{PENDAHULUAN}

Hutan mangrove diketahui mampu memberikan perlindungan seperti peredam gelombang dan perangkap sedimen terhadap pesisir (Murdiyarso et al., 2009). Danielsen et al. (2005) menyebutkan bahwa hutan mangrove merupakan vegetasi pantai yang paling penting di sepanjang pantai karena dapat membantu dalam mengurangi kerusakan yang disebabkan oleh gelombang tsunami. Mangrove dengan kondisi rapat mampu meredam gelombang laut lebih kuat dibandingkan dengan kondisi mangrove yang jarang atau telah rusak. Keberlangsungan ekosistem mangrove tersebut merupakan aspek penting karena berkaitan dengan pengurangan atau penambahan akumulasi sedimen. Proses masukan dan pengurangan sedimen pada mangrove berpotensi memainkan peran utama dalam menstabilkan tanah mangrove (Lee et al., 2014). Pasang surut, arus, gelombang, gradien salinitas dan topografi habitat mangrove saling berinteraksi dan memengaruhi proses akumulasi sedimen tersebut dengan berbagai cara yang kompleks (Hogarth, 2015). Proses akumulasi sedimen di wilayah ekosistem mangrove merupakan penumpukan partikel yang berasal dari sedimen laut maupun daratan melalui proses transportasi dan deposisi sedimen, serta berasal dari serasah mangrove yang jatuh (Adame et al., 2010).

Ekosistem Mangrove di Tanjung Batu terdiri dari mangrove rapat (kondisi mangrove dengan tutupan sangat rapat) dan mangrove muda (kondisi lahan dengan tutupan mangrove jarang) (BLH, 2011). BLH (2011) juga menyebutkan bahwa mangrove di Tanjung Batu telah mengalami penurunan dari tahun 2001-2010 yang disebabkan oleh aktivitas masyarakat seperti penebangan pohon, pembukaan lahan untuk tambak dan perkebunan kelapa sawit, sehingga dapat memengaruhi kondisi lahan hutan mangrove. Perubahan alih fungsi lahan yang terjadi di wilayah pesisir yang diduga dapat menyebabkan terjadinya degradasi lingku- ngan berupa akresi/sedimentasi (Dhiauddin et al., 2017). Kondisi geomorfologi tersebut menentukan respon mangrove terhadap perubahan lingkungan seperti penambahan atau pun pengurangan sedimen (Adame et al., 2010). Ekosistem mangrove di pesisir Tanjung Batu Kecamatan Kepulauan Derawan diperkirakan mampu memberikan kontribusi terhadap proses akumulasi sedimen melalui aliran-aliran sungai. Pengurangan ataupun penambahan akumulasi sedimen tersebut dapat ditentukan melalui pengukuran laju akumulasi sedimen.

Sedimen trap merupakan salah satu metode yang digunakan untuk melihat laju akumulasi sedimen berdasarkan jumlah (volume dan berat) sedimen yang mengendap per satuan luas area per waktu (Arifiani et al., 2015). Namun, sedimen trap dianggap kurang efisien apabila digunakan dalam interval waktu yang berskala tahunan. Metode terbaru untuk mengukur laju akumulasi sedimen salah satunya adalah dengan menggunakan radionuklida alam $\mathrm{Pb}-$ 210. Pb-210 merupakan metode yang tepat untuk studi ini karena mempunyai waktu paruh 22,26 tahun, sehingga cocok untuk menentukan sedimentasi yang berumur dibawah 200 tahun. Pb-210 mudah terserap dalam sedimen berukuran halus, sehingga banyak ditemukan di dalam sedimen di seluruh permukaan bumi. Radionuklida $\mathrm{Pb}-$ 210 adalah salah satu anak luruh U-238, keberadaannya dalam sedimen berasal dari proses: 1.) Ra-226 meluruh dan terbentuk gas Rn-222 yang terpancar ke udara hingga terbentuk Pb-210 (unsupported/excess), kemudian turun ke permukaan dan berikatan dengan partikel suspensi dan mengendap bersamaan membentuk lapisan sedimen, 2.) yang terbentuk karena adanya peluruhan $\mathrm{Ra}-$ 226 yang terdapat dalam sedimen tersebut melalui proses kesetimbangan dan meluruh menjadi $\mathrm{Pb}-210$ (supported) (IAEATECDOC-1360, 2003; Lubis et al., 2007). Aktivitas $\mathrm{Pb}-210$ berkaitan erat dengan waktu sedimentasi, sehingga dapat digunakan untuk memprediksi kecepatan sedimen, 
sedangkan konsentrasi $\mathrm{Pb}-210$ berhubungan dengan jumlah akumulasi sedimen (Witasari, 2015).

Penelitian terdahulu yang berkaitan dengan laju akumulasi sedimen menggunakan radionuklida $\mathrm{Pb}-210$ telah dilakukan oleh Lubis et al. (2007) di Teluk Jakarta dengan laju akumulasi sedimen dalam $\mathrm{cm}$ tahun $^{-1}$ berkisar antara 0,074-0,852 $\mathrm{cm}^{\text {tahun }}{ }^{-1}$. Laju akumulasi sedimen tertinggi di Teluk Jakarta terjadi sejak tahun 1970-an dan berkorelasi dengan adanya perubahan di daerah hulu dan sepanjang aliran sungai yang juga teridentifikasi sejak tahun 1970-an. Hal tersebut berkaitan dengan peningkatan populasi dan perkembangan pembangunan di Jakarta. Selain itu, Paputungan et al. (2016) menyebutkan bahwa laju akumulasi sedimen dalam $\mathrm{g} \mathrm{cm}^{-2}$ tahun $^{-1}$ di area restorasi mangrove Teluk Lembar-Pulau Lombok dalam 20 tahun terakhir berkisar $0,17-0,42 \mathrm{~g} \mathrm{~cm}^{-2}$ tahun $^{-1}$. Proses restorasi mangrove mampu mengembalikan fungsi mangrove sebagai perangkap sedimen di area pesisir. Hal tersebut ditunjukkan dengan laju tertinggi di lokasi restorasi dengan umur paling tua, sedangkan laju akumulasi sedimen terendah berada di lokasi restorasi yang masih baru.

Penelitian terkait laju akumulasi sedimen menggunakan radionuklida $\mathrm{Pb}-210$ di kawasan ekosistem mangrove Tanjung Batu belum pernah dilakukan karena penelitian terdahulu hanya berfokus pada struktur komunitas mangrove (Mukhlisi \& Sidiyasa, 2014; JALA, 2015). Selain itu, mengingat telah terjadi degradasi di kawasan ekosistem mangrove Tanjung Batu seperti konversi lahan menjadi tambak dan perkebunan kelapa sawit (Mukhlisi \& Sidiyasa, 2014; JALA, 2015), perlu dilakukan studi mengenai laju akumulasi sedimen mangrove. Tujuan dari penelitian ini adalah sebagai studi awal untuk mengestimasi laju akumulasi sedimen di kawasan ekosistem mangrove Tanjung Batu Kecamatan Kepulauan Derawan, BerauKalimantan Timur.

\section{METODE PENELITIAN}

\subsection{Waktu dan Tempat Penelitian}

Pengambilan data mangrove dilakukan pada bulan Februari 2018, sedangkan sedimen corring dilakukan pada bulan Februari (semua stasiun pada kedalaman 0$15 \mathrm{~cm}$ ) dan Mei (Stasiun 5 pada kedalaman 1-50 cm, Stasiun 1 dan 3 pada kedalaman 40$50 \mathrm{~cm}) 2018$ di hutan mangrove Tanjung Batu, Kecamatan Kepulauan DerawanKalimantan Timur. Pengambilan data dilakukan pada 3 titik stasiun (Figure 1) yang mewakili wilayah dekat daratan (Stasiun 5), mulut sungai (Stasiun 3), dan dekat pantai (Stasiun 1). Pemilihan stasiun tersebut berdasarkan pengaruh dari lautan dan daratan karena diperkirakan lokasi dekat dengan lautan dan daratan memiliki karakteristik proses akumulasi sedimen yang berbeda. Analisis butir sedimen dilakukan di Laboratorium Tanah Pusat Studi dan Rehabilitasi Hutan Universitas Mulawarman, Samarinda-Kalimantan Timur dan analisis radionuklida $\mathrm{Pb}-210$ di Laboratorium Kelautan dan Kimia, Bidang Industri dan Lingkungan, Pusat Aplikasi Isotop dan Radiasi, Badan Tenaga Nuklir Nasional, Jakarta Selatan.

\subsection{Prosedur dan Analisis Data \\ 2.2.1. Pengambilan Sampel}

Transek lingkaran berdiameter $7 \mathrm{~m}$ dibuat pada setiap stasiun untuk mengidentifikasi spesies mangrove yang mendominasi dan mengukur diameter batang pohon atau DBH (Kauffman \& Donato, 2012). Struktur komunitas mangrove dianalisis berdasarkan identifikasi spesies dan pengukuran DBH pada seluruh pohon yang memiliki tinggi lebih dari $130 \mathrm{~cm}$ untuk menentukan kerapatan pohon mangrove (Marchio et al., 2016; Kauffman et al., 2011).

Penentuan kerapatan mangrove menggunakan persamaan berikut:

Kerapatan $=\frac{\text { jumlah individu (individu) }}{\text { luas petaksampel (hektar) }}$ 


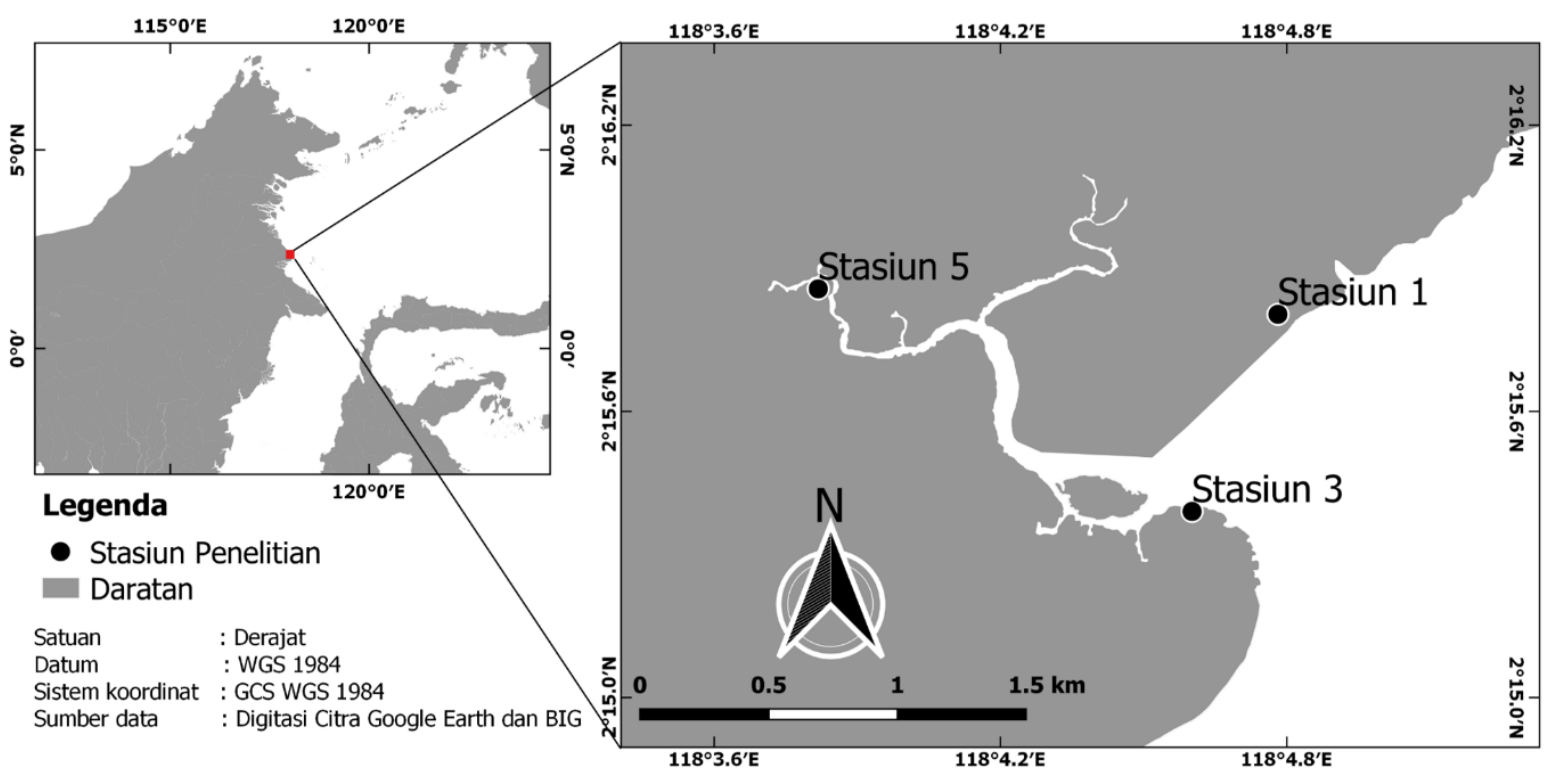

Figure 1. The research location and data collection point in the mangrove ecosystems of Tanjung Batu, Kepulauan Derawan regency-Kalimantan Timur province.

Pengambilan sampel sedimen dilakukan di titik tengah radius 7 m pada setiap titik stasiun. Panjang sampel sedimen semua stasiun adalah $50 \mathrm{~cm}$ yang selanjutnya pada Stasiun 1 dan 3 dipotong dengan interval 5 $\mathrm{cm}$ (pada kedalaman sedimen $0-15 \mathrm{~cm}$ ), dan diambil sedimen ketebalan $2 \mathrm{~cm}$ pada kedalaman 48-50 cm yang digunakan sebagai $\mathrm{Pb}-210$ supported. Jumlah total sampel sedimen dari Stasiun 1 dan 3 sebanyak 8 sampel. Pada stasiun 5 dipotong dengan interval 4, 6 dan $8 \mathrm{~cm}$ pada kedalaman 1-50 $\mathrm{cm}$, sehingga jumlah sampel dari Stasiun 5 sebanyak 9 sampel. Pemotongan sub-inti sedimen Stasiun 1 dan 3 berbeda dengan Stasiun 5 karena Stasiun 1 dan 3 memiliki substrat pasir, sehingga hanya diambil sampel sedimen pada lapisan permukaan dan lapisan dalam (mengingat keterbatasan tracer $\mathrm{Pb}-210$ di laboratorium). Pada Stasiun 5 diambil corring penuh dari lapisan permukaan, tengah dan dalam karena memiliki substrat liat. Tiap sub-sampel dimasukkan ke dalam plastik klip dan ditempatkan di cool box pada suhu $4{ }^{\circ} \mathrm{C}$, selanjutnya dibawa ke laboratorium (Sanchez-Cabeza et al., 1999). Setiap sub-sampel di laboratorium dikeringkan dengan oven pada suhu $60{ }^{\circ} \mathrm{C}$ hingga mencapai berat kering yang stabil (Kauffman \& Donato, 2012). Tiap sub-sampel sedimen dilakukan analisis $\mathrm{Pb}-210$ dan ukuran butir sedimen.

\subsubsection{Pengukuran $\mathbf{P b}-210$}

Sampel sedimen kering diambil sebanyak 5 g dan ditambahkan larutan Po-209 standar sebanyak $0,169 \mathrm{~Bq}$ sebagai internal tracer. Sampel sedimen didestruksi menggunakan asam kuat $\mathrm{HCl}$ (1:1) sebanyak 10 $\mathrm{ml}, \mathrm{HNO}_{3}(1: 1)$ sebanyak $10 \mathrm{ml}$, larutan aquades sebanyak $15 \mathrm{ml}$ dan 4-5 tetes $\mathrm{H}_{2} \mathrm{O}_{2}$ (30 \%). Pb-210 mudah teradsorbsi oleh partikel-partikel lempung atau bahan organik yang tersuspensi di kolom air, selanjutnya beragregasi dan mengendap ke dasar perairan (sedimen) (Szmytkiewicz \& Zalewska, 2014).

Selain dengan proses pengasaman, proses destruksi juga dilakukan dengan pemanasan menggunakan waterbath pada suhu $80{ }^{\circ} \mathrm{C}$ hingga sampel kering. Sampel yang telah kering ditambahkan larutan $\mathrm{HCl}(1: 1)$ sebanyak $10 \mathrm{ml}$ dan aquades sebanyak $40 \mathrm{ml}$ dan kemudian dipanaskan selama 10 menit pada suhu $80^{\circ} \mathrm{C}$. Fase larutan dipisahkan dari sedimen menggunakan kertas saring 
Whatman No. 42 dan filtrat hasil saringan tersebut dikeringkan hingga terbentuk endapan kering. Endapan tersebut dilarutkan dengan $4 \mathrm{ml} \mathrm{HCl} \mathrm{(1:1)} \mathrm{dan} \mathrm{ditepatkan} \mathrm{hingga}$ $50 \mathrm{ml}$ dengan menambahkan $\mathrm{HCl} 0,3 \mathrm{~N}$. Larutan ditambahkan $400 \mathrm{mg}$ asam askorbat dan dipanaskan selama 10 menit pada suhu $80{ }^{\circ} \mathrm{C}$, dengan tujuan mengurangi unsur besi (Fe) dan mencegah proses pengendapan $\mathrm{Fe}$ (Bakar et al., 2011). Larutan tersebut diaduk dalam tabung (tube) yang telah ditempatkan plat tembaga tahan karat (stainless-steel disk) untuk menangkap pengendapan Po-210 dan Po-209 menggunakan stirrer. Contoh tersebut dicacah dengan menggunakan spektrometer alfa tipe Canberra dengan detektor PIPS (Passiveted Implanted Planar Silicon) model A450-20AM, dengan area $450 \mathrm{~mm}^{2}$, resolusi $20 \mathrm{keV}$ pada kondisi vakum, dan energi yang digunakan adalah $4.88 \mathrm{MeV}$ untuk Po-209 dan 5.305 MeV untuk Po-210 (Lubis et al., 2007; Bakar et al., 2011; Sanchez-Cabeza et al., 1999).

Aktivitas total $\mathrm{Pb}-210(\mathrm{Pbt})$ diperoleh dari pengukuran isotop Po-210 dengan menggunakan spektrometer alfa. Selanjutnya $\mathrm{Pb}$ 210 supported ditentukan berdasarkan nilai aktivitas $\mathrm{Pb}-210$ total $\left(\mathrm{Pb}_{\mathrm{t}}\right)$ yang tetap atau cenderung tidak berubah terhadap kedalaman lapisan sedimen (Sanchez-Cabeza et al., 1999). $\mathrm{Pb}-210$ unsupported $\left(\mathrm{Pb}_{\mathrm{us}}\right)$ ditentukan berdasarkan persamaan berikut:

$P b_{u s}=P b_{t}-P b_{\text {supported }}$

$\mathrm{Pb}-210$ unsupported digunakan untuk mengukur umur dan laju akumulasi massa setiap lapisan (Szmytkiewicz \& Zalewska, 2014). Penentuan umur dan laju akumulasi sedimen dalam Mass Accumulation Rate (MAR) berdasarkan nilai Pb-210 unsupported dengan menggunakan model Constan Rate of Supply (CRS). Model CRS dikembangkan pertama kali oleh Appleby \& Oldfield, (1978) dengan prinsip laju akumulasi sedimen tidak konstan dan model ini lebih umum digunakan. Model ini mengasumsikan bahwa perubahan $\mathrm{Pb}-210$ pada sedimen adalah konstan dan laju akumulasi sedimen berubah (Willard \& Holmes, 1997). Konsentrasi $\mathrm{Pb}-210$ unsupported (berlebih) terhadap kedalaman sedimen dipengaruhi oleh proses sedimentasi (Boer et al., 2006; Szmytkiewz dan Zalewska, 2014). Metode ini digunakan dalam perhitungan umur sedimen dengan kedalaman lapisan sedimen yang tipis (Appleby \& Oldfield, 1978). Oleh karena itu, studi ini menggunakan model CRS. Persamaan dari model CRS dalam menentukan umur sedimen adalah sebagai berikut:

$A 0=A e^{-\lambda t}$

Keterangan: $\mathrm{A} 0=$ total $\mathrm{Pb}-210$ unsupported dari kedalaman inti sedimen $\left(\mathrm{Bq} \mathrm{m} \mathrm{m}^{-2}\right)$; $\mathrm{A}=$ $\mathrm{Pb}-210$ unsupported pada interval kedalaman sedimen tertentu $\left(\mathrm{Bq} \mathrm{m}^{-2}\right) ; \lambda=$ konstanta laju peluruhan $\mathrm{Pb}-210\left(0,0311\right.$ tahun $\left.^{-1}\right) ; \mathrm{t}=$ umur (tahun). Laju akumulasi sedimen tiap lapisan sedimen dihitung dengan menggunakan persamaan berikut (Boer et al., 2006):

$S=\frac{\lambda \mathrm{A}}{\mathrm{Pbus}}$

Keterangan: $\mathrm{S}=$ laju akumulasi sedimen dalam mass accumulation rate/MAR $\left(\mathrm{g} \mathrm{cm}^{-2}\right.$ tahun $\left.^{-1}\right) ; \lambda=$ konstanta laju peluruhan $\mathrm{Pb}-210$ $\left(0.0311\right.$ tahun $\left.^{-1}\right)$; Pbus $=\mathrm{Pb}-210$ unsupported tiap lapisan sedimen $\left(\mathrm{Bq} \mathrm{kg}{ }^{-1}\right) ; \mathrm{A}=\mathrm{Pb}-210$ unsupported di bawah interval kedalaman tertentu $\left(\mathrm{Bq} \mathrm{m}^{-2}\right)$.

\subsubsection{Tekstur Sedimen}

Pengukuran tekstur sedimen dilakukan untuk melihat sebaran ukuran diameter sedimen. Pada penelitian ini tekstur sedimen diukur berdasarkan 3 fraksi yaitu liat, lanau dan pasir. Pengukuran dilakukan menggunakan metode pipet (untuk memisahkan lanau dan liat) dan ayakan basah (untuk memisahkan pasir dan lumpur menggunakan mesh ukuran $500 \mu \mathrm{m}, 125 \mu \mathrm{m}$ dan $63 \mu \mathrm{m}$ ). Proses destruksi bahan organik dilakukan terhadap sampel sedimen sebelum pengukuran tekstur sedimen dengan menggunakan 
laurutan $\mathrm{H}_{2} \mathrm{O}_{2}$ (Sanders et al., 2010). Proses destruksi bahan organik bertujuan mengurangi sumbangsih bobot sedimen dan bahan organik.

\section{HASIL DAN PEMBAHASAN}

\subsection{Stuktur Komunitas Mangrove}

Jenis mangrove yang ditemukan dalam studi ini adalah Camptostemon philippinense, Rizhopora stylosa, $R$. mucronata, $R$. apiculata, Ceriops tagal, dan Bruguiera gymnorrhiza. C. philippinense merupakan jenis mangrove yang mendominasi Stasiun 1 dan 5, sedangkan $R$. mucronata mendominasi di Stasiun 3 (Table 1). C. philippinense merupakan jenis mangrove yang masuk ke dalam red list dengan penyebaran hanya ada di Kalimantan, Sulawesi dan Filipina (Duke et al., 2010). $R$. mucronata merupakan jenis umum yang sering dijumpai di berbagai wilayah termasuk dalam studi ini.

Total kerapatan pohon $(\mathrm{DBH}<5$ dan $>5 \mathrm{~cm}$ ) tertinggi adalah Stasiun 1 (mangrove dekat pantai), sedangkan terendah adalah Stasiun 3 (mangrove dekat mulut sungai). Perbedaan komposisi kerapatan berdasarkan $\mathrm{DBH}<5$ dan $>5 \mathrm{~cm}$ memengaruhi total kerapatan mangrove. Stasiun 1 didominasi jumlah pohon dengan $\mathrm{DBH}>5 \mathrm{~cm}$ dibandingkan dengan Stasiun 3 dan 5, sehingga memiliki kerapatan paling tinggi. Stasiun 3 memiliki jumlah pohon dengan
DBH > $5 \mathrm{~cm}$ terendah, sehingga memiliki kerapatan rendah. Hal tersebut sesuai dengan pernyataan Paputungan et al. (2016), mangrove pada zona laut memiliki pohon-pohon lebih besar dalam jumlah yang banyak dibandingkan dengan mangrove pada zona tergenang.

JALA (2015) melaporkan kerapatan total di 2 lokasi bagian dari Tanjung Batu yaitu Bulalung dan Mangkarangu berturutturut adalah 19.600 dan 9.875 individu ha ${ }^{-1}$. Kerapatan tersebut lebih tinggi daripada hasil studi. Hal tersebut mengindikasikan bahwa mangrove di Tanjung Batu telah mengalami penurunan dari tahun 2015 hingga tahun 2018. Penurunan kerapatan dalam studi ini diduga adanya penebangan pohon yang terus menerus dilakukan oleh masyarakat sekitar untuk pembuatan bagan-bagan penangkap ikan di tengah laut dalam beberapa tahun terakhir.

DBH yang relatif berukuran besar pada mangrove diduga akan menyebabkan biomassa pohon meningkat. Hal tersebut sesuai dengan pernyataan bahwa total biomassa meningkat dengan bertambahnya usia (Alongi, 2002; Paputungan et al., 2016). Stasiun 1 dan 5 (Table 1) diduga memiliki biomassa yang relatif lebih besar daripada Stasiun 3, karena nilai kerapatan pohon Stasiun 1 dan 5 lebih tinggi daripada Stasiun 3. Perbedaan kerapatan pohon akan berpengaruh pada biomassa pohon dan merupakan indikasi awal perbedaan laju akumulasi

Table 1. Mangrove density based on species and DBH (individu $\mathrm{ha}^{-1}$ ). The sign (-) identifies no mangrove species found.

\begin{tabular}{lccc}
\hline \multicolumn{1}{c}{ Tree structure } & Station 1 & Station 3 & Station 5 \\
\hline C. philippinense & 3704 & 715 & 1104 \\
R. stylosa & 1559 & - & - \\
R. mucronata & - & 3769 & - \\
R. apiculata & - & - & 519 \\
C. tagal & - & - & - \\
B. gymnorrhiza & - & - & 2989 \\
\hline Total of density & 5363 & 4484 & 6107 \\
\hline DBH $<5 \mathrm{~cm}$ & 2114 & 2210 & 3183 \\
DBH $>5 \mathrm{~cm}$ & 3249 & 2274 & 2924 \\
\hline
\end{tabular}


sedimen. Studi sebelumnya juga menyebutkan bahwa perbedaan biomassa vegetasi merupakan indikasi awal perbedaan laju akumulasi sedimen (Paputungan et al., 2016).

\subsection{Estimasi Waktu Pengendapan Sedimen dan Laju Akumulasi Sedimen}

Profil $\mathrm{Pb}-210$ di Stasiun 1, 3 dan 5 berkurang terhadap kedalaman secara eksponensial (Figure 2). Meskipun hasil aktivitas total $\mathrm{Pb}-210$ yang dihasilkan tiap-tiap stasiun berbeda nilainya, namun dari ketiga stasiun tersebut membentuk pola yang sama. Total Pb-210 Stasiun 1 berkisar 9,81-15,62 $\mathrm{Bq} \mathrm{kg}{ }^{-1}$, Stasiun 3 berkisar 23,14-38,07 $\mathrm{Bq}$ $\mathrm{kg}^{-1}$ dan Stasiun 5 berkisar 23,84-61,17 Bq $\mathrm{kg}^{-1}$. Pada lapisan permukaan sedimen (lapisan sedimen yang relatif lebih muda) memiliki nilai aktivitas total cenderung lebih tinggi dan menurun seiring bertambahnya kedalaman (lapisan sedimen yang relatif lebih tua sekitar kedalaman lebih dari 15 $\mathrm{cm})$.

Stasiun 5 menunjukkan pola eksponensial yang terlihat lebih jelas dibandingkan dengan stasiun lainnya. Aktivitas total Stasiun 5 menunjukkan 20 kali lebih besar dibandingkan Stasiun 3 dan 40 kali lebih besar dari Stasiun 1, namun ketiga stasiun tersebut memiliki pola yang sama. Perbedaan nilai tersebut dikarenakan pengambilan contoh corring pada Stasiun 1 dan 3 berbeda dengan Stasiun 5. Corring Stasiun 5 diambil penuh pada kedalaman $0-50 \mathrm{~cm}$, sedangkan pada Stasiun 1 dan 3 hanya diambil corring pada lapisan permukaan dan lapisan dalam sedimen. Corring Stasiun 1 dan 3 diambil sedemikian rupa karena hasil fraksinasi sedimen pada Stasiun 1 dan 3 didominasi oleh substrat pasir (Figure 3), sehingga apabila diambil pada kedalaman $50 \mathrm{~cm}$ akan menghasilkan data yang sama dengan pengambilan pada lapisan permukaan mau pun lapisan dalam (mengingat keterbatasan ketersediaan tracer $\mathrm{Pb}-210$ di laboratorium).

Lapisan yang lebih dalam pada sebuah core menunjukkan waktu yang lebih tua karena peluruhan radioaktif diasumsikan sebagai indikasi dari penurunan konsentrasi terhadap kedalaman (Jeter, 2000). Stasiun 1 dan 3 memiliki substrat pasir yang lebih tinggi dibandingkan Stasiun 5 (Figure 3). Substrat pasir mengindikasikan tingginya proses erosi yang menyebabkan gangguan deposisi $\mathrm{Pb}-210$ di sedimen. Hal ini berimplikasi terhadap nilai ketidakpastian dalam mengestimasi umur sedimen dengan menggunakan model CRS dan perhitungan laju akumulasi sedimen (Jeter, 2000; Smoak et al., 2012).

\section{Total activity $\left(\mathrm{Bq} \mathrm{kg}^{-1}\right)$ Station 1} $\begin{array}{llllllll}0 & 10 & 20 & 30 & 40 & 50 & 60 & 70\end{array}$

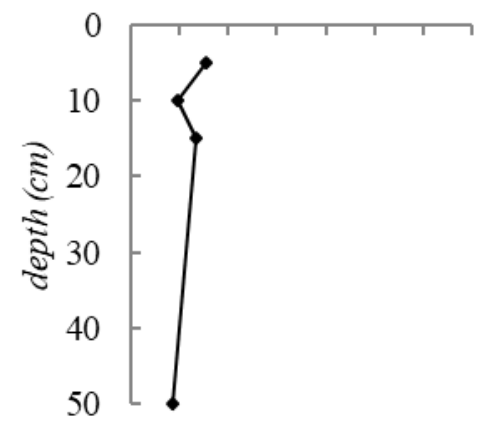

\section{Total activity $\left(B q \mathrm{~kg}^{-1}\right)$ Station 3} $0 \quad 10203040506070$

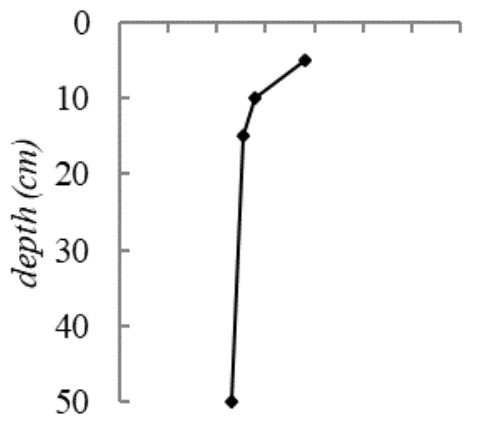

Total activity $\left(B q \mathrm{~kg}^{-1}\right)$ Station 5

010203040506070

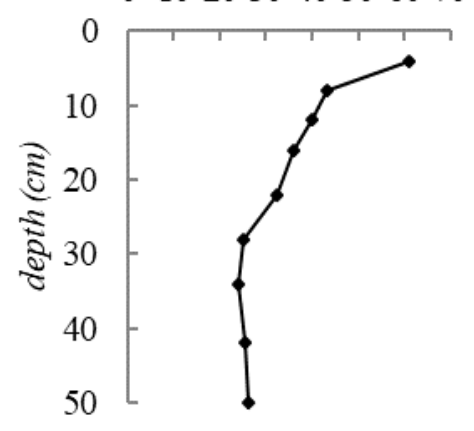

Figure 2. The total activity profile of $\mathrm{Pb}-210\left(\mathrm{~Bq} \mathrm{~kg} \mathrm{~g}^{-1}\right)$ at Stations 1,3 dan 5 on sediment depth $(\mathrm{cm})$. 
Estimasi waktu pengendapan sedimen pada profil vertikal sedimen di Stasiun 1, 3 dan 5 secara berurutan dapat dihitung hingga kedalaman $10 \mathrm{~cm}, 10 \mathrm{~cm}$, dan $22 \mathrm{~cm}$ (Figure 4). Estimasi waktu pengendapan sedimen di Stasiun 1, 3 dan 5 pada lapisan permukaan menunjukkan tahun yang lebih muda atau umur sedimen yang lebih muda (Figure 4). Waktu pengendapan bertambah semakin tua dengan bertambahanya kedalaman sedimen. Hasil studi menunjukkan Stasiun 1 berumur antara tahun 1960 dan 2000, Stasiun 3 berumur antara tahun 1940 dan 1980 serta Stasiun 5 berumur antara tahun 1911 dan 2007. Menurut Jeter (2000) nilai Pb-210 yang menyebar berkaitan dengan lapisan berpasir dihasilkan oleh energi erosi yang besar. Analisis butir sedimen di Stasiun 1 dan 3 adalah pasir (Figure 3) menunjukkan adanya gangguan perhitungan aktivitas $\mathrm{Pb}$ 210.

Hasil analisis menggunakan model CRS menunjukkan profil ketiga sedimen inti hampir sama, Stasiun 1 dan 3 yang hanya menggunakan sedimen pada kedalaman 0-15 $\mathrm{cm}$ dan 40-50 $\mathrm{cm}$ menunjukkan umur yang lebih muda dibandingkan dengan Stasiun 5 yang menggunakan sampel sedimen penuh pada kedalaman 0-50 cm (Figure 4). Pada kedalaman maksimum yang dapat diukur, sedimen Stasiun 1 berumur 57 tahun pada kedalaman $10 \mathrm{~cm}$, sedimen Stasiun 3 ber- umur 69 tahun pada kedalaman $10 \mathrm{~cm}$, sedangkan Stasiun 5 berumur paling tua yaitu 107 tahun pada kedalaman $22 \mathrm{~cm}$. Hal tersebut menjadi indikasi awal lebih tinggi atau rendahnya masukan sedimen di stasiun dekat lautan, mulut sungai dan dekat sungai/daratan. Secara keseluruhan, pada kedalaman 0-10 cm, Stasiun 3 merupakan stasiun dengan sedimen berumur paling tua dengan selisih 12 tahun dari Stasiun 1 dan selisih 45 dari Stasiun 5. Hal tersebut menunjukkan Stasiun 3 pada kedalaman $10 \mathrm{~cm}$ memiliki masukan sedimen paling tinggi dari Stasiun 1 dan 5.

Pengukuran aktivitas total $\mathrm{Pb}-210$ yang digunakan untuk mengestimasi waktu pengendapan sedimen, selanjutnya digunakan untuk menghitung laju akumulusi sedimen. Laju akumulasi sedimen dalam Mass Accumulation Rate (MAR) $\left(\mathrm{g} \mathrm{cm}^{-2}\right.$ tahun $\left.^{-1}\right)$ berdasarkan kedalaman sedimen $(\mathrm{cm})$ pada Stasiun 1, 3 dan 5 menunjukkan nilai yang bervariasi (Figure 5). Akumulasi sedimen pada Stasiun 1 lebih besar pada lapisan 0-5 $\mathrm{cm}$ yaitu $0,206\left(\mathrm{~g} \mathrm{~cm}^{-2}\right.$ tahun $\left.^{-1}\right)$ periode 1998 2018 dibandingkan dengan lapisan $5-10 \mathrm{~cm}$ sebesar $0,092\left(\mathrm{~g} \mathrm{~cm}^{-2}\right.$ tahun $\left.^{-1}\right)$ periode tahun 1961-1998. Stasiun 3 menunjukkan bahwa akumulasi sedimen pada lapisan $0-5 \mathrm{~cm}$ sebesar $0,106\left(\mathrm{~g} \mathrm{~cm}^{-2}\right.$ tahun $\left.^{-1}\right)$ periode 1978 2018 dan tidak jauh berbeda pada lapisan 5$10 \mathrm{~cm}$ sebesar $0,114\left(\mathrm{~g} \mathrm{~cm}^{-2}\right.$ tahun $\left.^{-1}\right)$ periode
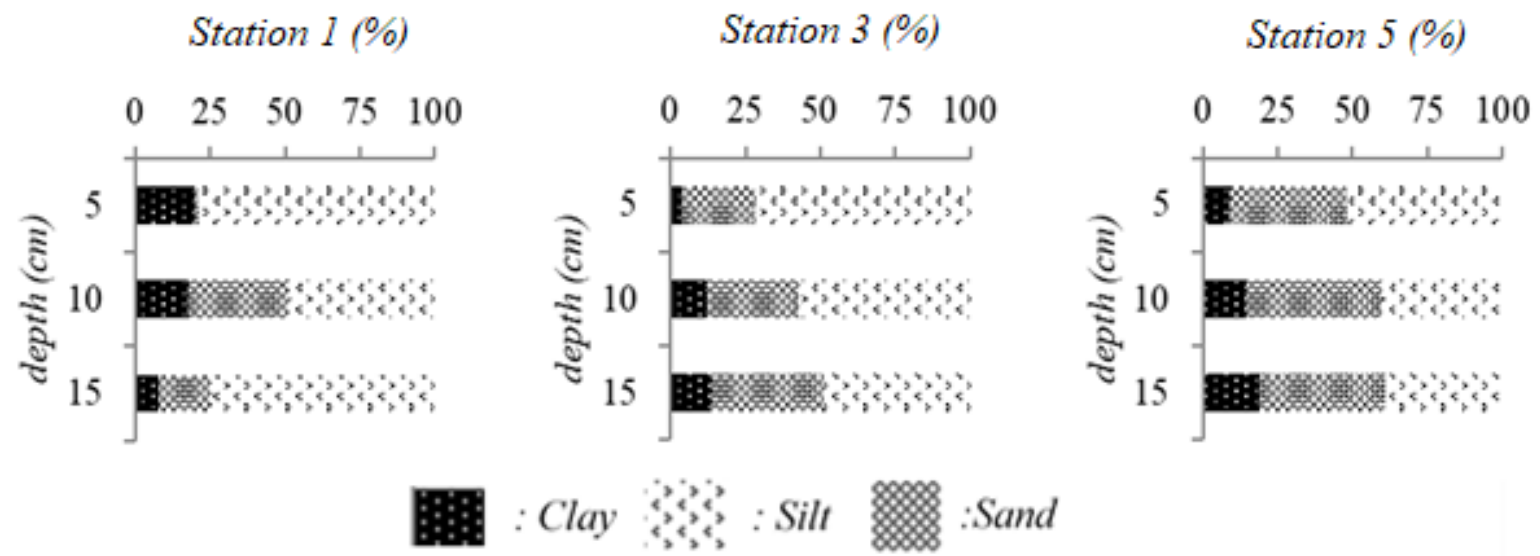

Figure 3. The concentrations (\%) grain size of clay, silt and sand sediments at Stations 1, 3 and 5 based on sediment depth (cm). 


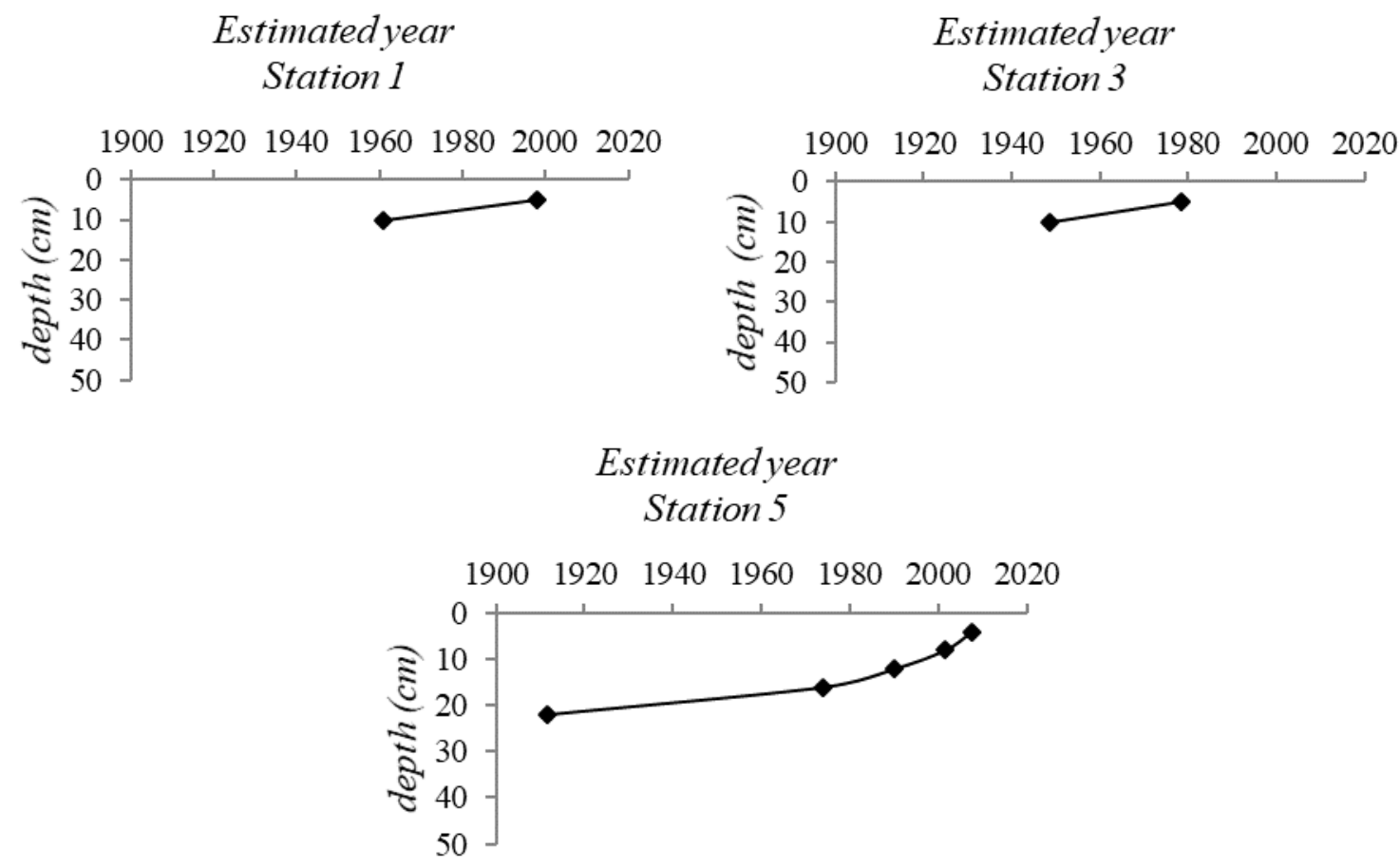

Figure 4. The Estimation of deposition time (years) for each sedimentary layer (cm).

1949-1978. Stasiun 5 merupakan stasiun dengan corring lebih panjang menunjukkan bahwa pada kedalaman $0-4 \mathrm{~cm}$ terjadi akumulasi sedimen sebesar $0,061\left(\mathrm{~g} \mathrm{~cm}^{-2}\right.$ tahun $\left.{ }^{1}\right)$ periode 2007-2018. Selanjutnya, pada lapisan 4-8 $\mathrm{cm}$ meningkat sebesar $0,90(\mathrm{~g}$ $\mathrm{cm}^{-2}$ tahun $^{-1}$ ) periode 2001-2007 dan mengalami penurunan akumulasi sedimen pada lapisan berikutnya. Pada lapisan kedalaman 16-22 cm menunjukkan akumulasi paling rendah dibandingkan semua lapisan di atasnya yaitu sebesar 0,036 terekam pada periode 1911-1974.

Secara keseluruhan, Stasiun 1 dan 3 pada kedalaman 1-10 $\mathrm{cm}$ menunjukkan bahwa laju akumulasi sedimen lebih tinggi jika dibandingkan dengan lapisan di bawah $10 \mathrm{~cm}$ pada Stasiun 5. Hal tersebut sejalan dengan penelitian Lubis et al. (2007) yang menjelaskan bahwa hasil studi akumulasi sedimen di Teluk Jakarta menunjukkan nilai akumulasi sedimen lebih besar di lapisan kedalaman 2-16 cm. Paputungan et al. (2016) juga menjelaskan bahwa laju akumulasi sedimen meningkat dari lapisan bawah ke lapisan permukaan sedimen yang menggambarkan kondisi terkini. Besarnya akumulasi sedimen dalam studi ini diduga adanya dampak dari konversi hutan mangrove yang cukup besar untuk kepentingan pembangunan tambak mau pun pemukiman dalam kurun waktu kurang lebih 9 tahun yaitu pada periode 2001-2009 (BLH, 2011). Proses konversi lahan berhubungan dengan besarnya akumulasi sedimen karena wilayah mangrove yang dikonversi akan merubah pola pengendapan sedimen dan berkurangnya vegetasi mangrove.

Rata-rata laju akumulasi sedimen berdasarkan setiap lapisan kedalaman Stasiun 1, 3 dan 5 secara berurutan adalah $0,15,0,12$ dan $0,07 \mathrm{~g} \mathrm{~cm}^{-2}$ tahun $^{-1}$ (Figure 5). Laju akumulasi sedimen tersebut menunjukkan adanya peningkatan akumulasi dari laut (tertinggi pada stasiun 1), kemudian mulut sungai (Stasiun 3) dan terendah dekat daratan/sungai (Stasiun 5). Hal tersebut sesuai dengan hasil penelitian Paputungan (2017) di area restorasi mangrove Dusun Cemere-Lombok yang melaporkan bahwa 

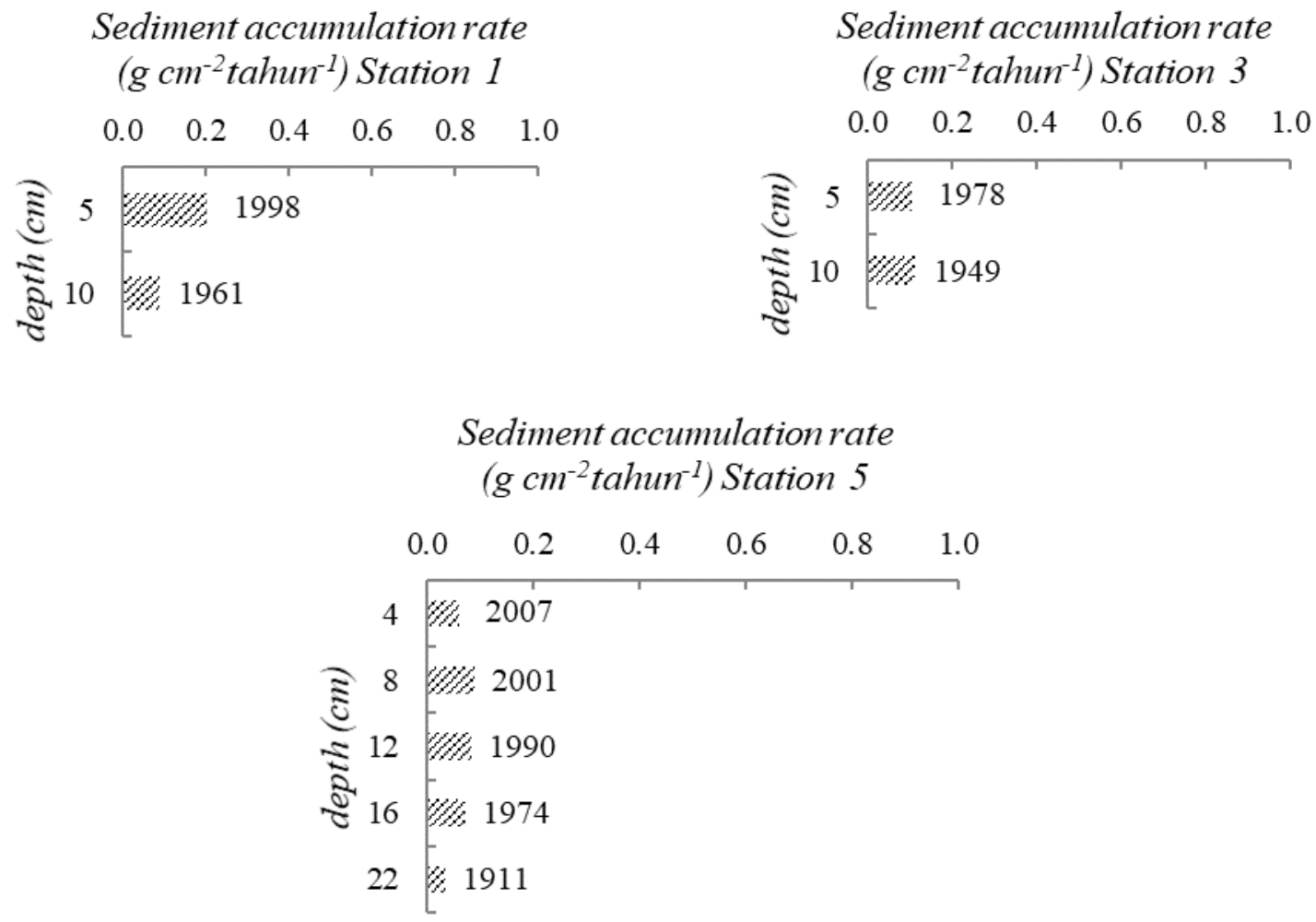

Figure 5. Sediment accumulation rate $\left(\mathrm{g} \mathrm{cm}^{-2}\right.$ tahun $\left.^{-1}\right)$ at Stastions 1,3 and 5 based on interval of sediments depth $(\mathrm{cm})$.

rata-rata laju akumulasi sedimen pada wilayah laut $\left(0,40 \mathrm{~g} \mathrm{~cm}^{-2}\right.$ tahun $\left.^{-1}\right)$ lebih tinggi daripada wilayah daratan/tergenang $(0,20 \mathrm{~g}$ $\mathrm{cm}^{-2}$ tahun $\left.^{-1}\right)$. Tingginya laju akumulasi sedimen di wilayah laut dipengaruhi oleh pasang surut dan waktu penggenangan wilayah laut lebih lama dibandingkan dengan wilayah daratan/tergenang (Paputungan, 2017). Faktor tersebut diduga juga mempengaruhi tingginya laju akumulasi sedimen di lokasi studi.

Rata-rata laju akumulasi sedimen hasil studi lebih rendah dibandingkan dengan rata-rata laju akumulasi sedimen mangrove alami yang ada di beberapa wilayah di Indonesia. Rata-rata laju akumulasi sedimen mangrove alami di Segara anakan Cilacap sebesar 2,4 $\mathrm{g} \mathrm{cm}^{-2}$ tahun $^{-1}$ (Kusumaningtyas et al., 2019). Selain itu, wilayah lain yang menunjukkan rata-rata akumulasi sedimen yang lebih tinggi adalah wilayah Berau secara keseluruhan mulai dari Tanjung Batu sampai dengan Biduk-biduk sebesar $\geq 1,6 \mathrm{~g}$ $\mathrm{cm}^{-2}$ tahun $^{-1}$ (Kusumaningtyas et al., 2019). Rendahnya rata-rata laju akumulasi sedimen di lokasi studi dan adanya variasi rata-rata laju akumulasi sedimen di area mangrove alami diduga oleh kondisi lingkungan setempat dan proses akumulasi sedimen.

Stasiun 1 dan 3 di kedalaman $10 \mathrm{~cm}$ memiliki rata-rata laju akumulasi sedimen lebih tinggi dari Stasiun 5, hal tersebut disebabkan oleh Stasiun 1 dan 3 lebih dekat dengan wilayah pantai/laut. Lokasi yang lebih dekat ke pantai dan muara sungai memberi kontribusi terhadap tebalnya endapan sedimen di daerah tersebut (Lubis et al., 2007). Selain itu, Stasiun yang memiliki kerapatan mangrove tinggi diperkirakan akan mampu melindungi sedimen mangrove dari beberapa faktor oseanografi. Herison et al. (2014) menyatakan mangrove di Pesisir Pantai Indah Kapuk yang memiliki kerapatan lebih tinggi dan distribusinya menyebar bebas akan mampu meredam gelombang pantai dan mengakumulasi sedimen yang 
lebih besar. Hal tersebut terbukti dengan hasil studi, bahwa Stasiun 1 memiliki kerapatan dengan $\mathrm{DBH}>5 \mathrm{~cm}$ lebih tinggi daripada Stasiun 3 dan 5. Stasiun 1 juga merupakan stasiun yang langsung berhadapan dengan laut dan diduga mendapat pengaruh gelombang lebih kuat dibandingkan Stasiun 3 dan 5. Hal tersebut mengakibatkan Stasiun 1 memiliki laju akumulasi sedimen tertinggi. Disisi lain, Stasiun 5 memiliki laju akumulasi sedimen terendah karena Stasiun 5 memiliki kerapatan mangrove dengan $\mathrm{DBH}>5 \mathrm{~cm}$ lebih rendah dari Stasiun 1 dan 3. Selain itu, karena letak Stasiun 5 jauh dari perairan laut sehingga Stasiun 5 terlindung oleh pengaruh gelombang laut. Perbedaan kondisi oseanografi tersebut diduga dapat memberikan pengaruh terhadap laju akumulasi sedimen di Stasiun 1, 3 dan 5. Pada ekosistem mangrove ada beberapa komponen yang berpengaruh dalam proses pengendapan partikel sedimen dan salah satunya adalah gelombang (Wolanski, 1995). Kondisi hutan mangrove yang memiliki kerapatan lebih tinggi akan mampu meredam gelombang karena sedimen yang terbawa akan terperangkap di akar mangrove. Kondisi lain seperti pasang tertinggi pada musim hujan juga akan mengangkut banyak sedimen ke daerah mangrove yang memiliki kerapatan tinggi (Mahmood et al., 2005). Dengan demikian, kerapatan mangrove yang tinggi mengidentifikasikan proses akumulasi sedimen yang tinggi dibandingkan dengan kerapatan mangrove yang rendah.

Laju akumulasi sedimen dalam MAR $\left(\mathrm{g} \mathrm{cm}^{-2}\right.$ tahun $^{-1}$ ) selama 20 tahun terakhir (1998-2018) di Stasiun 1, 3 dan 5 secara berurutan adalah 0,20, 0,11, 0,09 $\mathrm{g} \mathrm{cm}^{-2}$ tahun $^{-1}$ (Figure 6). Stasiun 1 dan 3 diduga dalam 20 tahun terakhir memiliki sumber akumulasi sedimen lebih besar yang berasal dari sungai/daratan, selanjutnya letak Stasiun 1 dan 3 tepat di depan perairan laut, sehingga mendapat pengaruh dari gelombang dan pasang surut air laut. Selain itu, Stasiun 1 memiliki DBH mangrove $>5 \mathrm{~cm}$ lebih tinggi daripada Stasiun 2 dan 3. Hasil studi oleh
Paputungan et al. (2016) di area restorasi mangrove Lombok Timur selama 20 tahun terakhir menyatakan bahwa laju akumulasi sedimen berkisar $0,17-0,42 \mathrm{~g} \mathrm{~cm}^{-2}$ tahun $^{-1}$ dengan laju akumulasi tertinggi adalah Stasiun 1, selanjutnya diikuti oleh Stasiun 2 dan 3. Stasiun 1 merupakan area mangrove yang memiliki pohon yang besar dan umur sedimen lebih tua dibandingkan dengan Stasiun 2 dan 3.

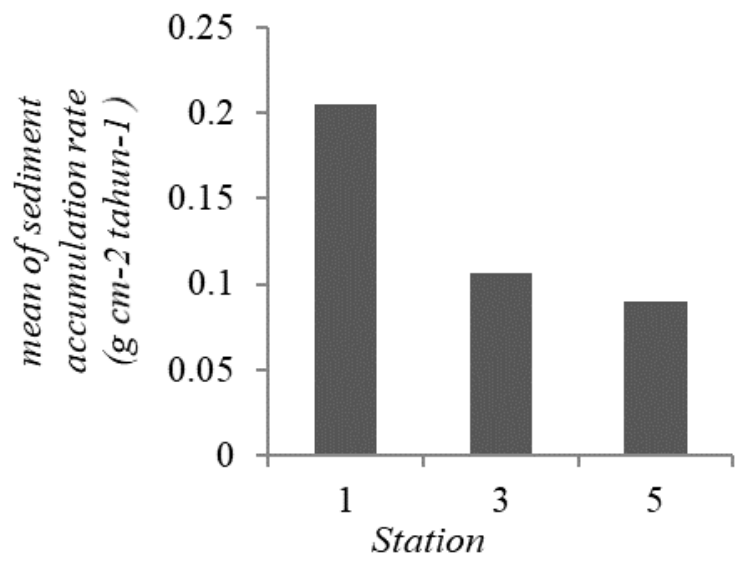

Figure 6. Rata-rata laju akumulasi sedimen the average of sediment accumulation rate $\left(\mathrm{g} \mathrm{cm}^{-2}\right.$ tahun $\left.^{-1}\right)$ at Stations 1, 3 and 5 based on sediment age in the last 20 years.

Dengan demikian, umur restorasi mangrove berpengaruh terhadap proses akumulasi di area restorasi mangrove Lombok. Nilai laju akumulasi sedimen hasil studi menunjukkan nilai yang tidak jauh berbeda dengan hasil studi Paputungan et al. (2016). Hal tersebut mengindikasikan bahwa telah terjadi gangguan di sekitar mangrove Tanjung Batu. Degradasi mangrove yang terjadi secara terus-menerus dapat menurunkan proses akumulasi sedimen di ekosistem mangrove (Lee et al., 2014). Erawan et al. (2018) juga menyebutkan bahwa degradasi tutupan lahan di atas aliran sungai dan tepi sungai akan menyebabkan debit sungai meningkat dan terjadi erosi di sepanjang aliran sungai. 


\section{KESIMPULAN}

Laju akumulasi sedimen di area studi selama 20 tahun terakhir (1998-2018) berkisar $0,09-0,20 \mathrm{~g} \mathrm{~cm}^{-2}$ tahun $^{-1}$. Proses akumulasi sedimen tersebut menunjukkan nilai yang lebih tinggi di stasiun dekat pantai/laut (Stasiun 1) dengan kerapatan mangrove didominasi oleh pohon berdiameter $>5 \mathrm{~cm}$, sedangkan paling rendah di stasiun dekat sungai/daratan (Stasiun 5) dengan kerapatan mangrove didominasi oleh pohon berdiameter $<5 \mathrm{~cm}$. Selain kerapatan mangrove sebagai faktor yang mempengaruhi laju akumulasi sedimen, kondisi oseanografi seperti (gelombang, pasang surut dan masukan/sumber dari sungai/daratan) diduga juga dapat memberikan pengaruh terhadap laju akumulasi sedimen di mangrove Tanjung Batu, untuk itu perlu dilakukan studi lanjutan terkait faktor oseanografi.

\section{UCAPAN TERIMAKASIH}

Penulis mengucapkan terimakasih kepada Beasiswa Kaltim Tuntas 2019 yang telah memberikan pendanaan penelitian. Ucapan terimakasih juga diberikan kepada Samsul Rizal, S.Pi., M.Si. yang telah memberikan fasilitas dan pendanaan penelitian.

\section{DAFTAR PUSTAKA}

Adame, M.F., D. Neil, S.F. Wright, \& C.E. Lovelock. 2010. Sedimentation within and among mangrove forest along a gradient geomorphological setting. Estuarine, Coast. and Shelf Sci., 86(1): 21-30. https://doi.org/10.1016/j.ecss.2009.10 .013

Alongi, D.M. 2002. Present state and future of the world's mangrove forests. Env. Conserv., 29(3): 331-349. https://doi.org/10.1017/S0376892902 000231

Appleby, P.G. \& F. Oldfield. 1978. The calculation of lead-210 dates assuming a constant rate of supply of unsupported $210 \mathrm{~Pb}$ to the sediment. Catena, 5(1): 1-8. https://doi.org/10.1016/S03418162(78)80002-2

Arifiani, S. Widada, \& D.N. Sugianto. 2015. Pengaruh longshore current terhadap laju sedimentasi di area jetty prophyline dan jetty cargo PT. Pertamina RU VI Balongan Indramayu. J. Ose UNDIP, 4(3): 598-607.

https://ejournal3.undip.ac.id/index.ph $\mathrm{p} /$ joce/article/view/9055/0

Badan Lingkungan Hidup (BLH). 2011. Laporan Penyusunan data base mangrove Kecamatan Kepulauan Derawan Kab. Berau Provinsi Kalimantan Timur. Berau. 44 p.

Bakar, Z.A., A. Saat, Z. Hamzah, A.K. Wood, \& Z. Ahmad. 2011. Sedimentation rate and chronology of As and $\mathrm{Zn}$ in sediment of a recent former tin mining lake estimated using $\mathrm{Pb}-210$ dating technique. Malaysian J. of Anal. Sci., 15(2): 150158. https://mjas.analis.com.my/wpcontent/uploads/2018/11/Zaharidah.p df

Boer, W., G.D. Van der Bergh, H. de Haas, H.C. de Stigter, R. Gieles, \& T.C.E. van Weering. 2006. Validation of accumulation rates in Teluk Banten (Indonesia) from commonly applied $210 \mathrm{~Pb}$ models, using the 1883 Krakatau tephra as time marker. Mar. Geol., 227(3-4): 263-277. https://doi.org/10.1016/j.margeo.2005 .12 .002

Danielsen, F., M.K. Sørensen, M.F. Olwig, V. Selvam, F. Parish, N.D. Burgess, T. Hiraishi, V.M. Karunagaran, M.S. Rasmussen, L.B. Hansen, A. Quarto, \& N. Suryadiputra. 2005. The Asian Tsunami: A protective role for coastal vegetation. Science, 310(5748): 643. https://doi.org/10.1126/science.11183 87 
Dhiauddin, R., W.A. Gemilang, U.J. Wisha, G.A. Rahmawan, \& G. Kusumah. 2017. Pemetaan kerentanan pesisir Pulau Simeulue dengan metode CVI (Coastal Vulnerability Index). Enviro Scienteae, 13(2): 157-170. https://doi.org/10.20527/es.v13i2.391 8

Duke, N., K. Kathiresan, S.G. Salmo III, E.S. Fernando, J.R. Peras, S. Sukardjo, T. Miyagi, J. Ellison, N.E. Koedam, Y. Wang, J. Primavera, O. Jin Eong, J. Wan-Hong Yong, \& V. Ngoc Nam. 2010. Camptostemon philippinense. The IUCN Red List of Threatened Species2010: e.T178808A7612909. https://doi.org/10.2305/IUCN.UK.201 0-2.RLTS.T178808A7612909.en

Erawan, M.T.F., T. Prartono, \& A. Arman. 2018. Characteristic of sediments deposition in Karimata Strait. ILMU KELAUTAN: Indonesian J. of Mar. Sci., 23(2): 93-98. https://doi.org/10.14710/ik.ijms.23.2. 93-98

Herison, A., F. Yulianda, C. Kusmana, I.W. Nurjaya, \& L. Adrianto. 2014. The existing condition of mangrove region of Avicennia marina: Its distribution and functional transformation. $J M H T$, 20(1): 26-34. http://doi.org/10.7226/jtfm.20.1.26

Hogarth, P.J. 2015. The biology of mangroves and Seagrass. Oxford Unversity. UK. 289 p.

IAEA-TECDOC-1360. 2003. Collection and preparation of bottom sediment samples for analysis of radionuclides and trace elements. International Atomic Energy Agency. Vienna. 63$82 \mathrm{pp}$.

Jaringan Nelayan (JALA). 2015. Survei biodiversitas kawasan hutan mangrove Kampung Tanjung Batu Kecamatan Pulau derawan Kabupaten Berau Kalimantan Timur. Berau. 20 p.
Jeter, H.W. 2000. Determining the ages of recent sediments using measurements of trace radioactivity. Terra Aqua., 78: 21-28.

https://hero.epa.gov/hero/index.cfm/r eference/details/reference_id/81760

Kauffman, J.B. \& D. Donato. 2012. Protocols for the measurement, monitoring and reporting of structure, biomass and carbon stocks in mangrove forests. Working Paper 86. CIFOR. Bogor, Indonesia. 40 p.

Kauffman, J.B., C. Heider, T.G. Cole, K.A. Dwire, \& D.C. Donato. 2011. Ecosystem carbon stock of micronesian mangrove forest. Wetlands, 31: 343-352. https://doi.org/10.1007/s13157-0110148-9

Kusumaningtya, M.A., A.A. Hutahaean, H.W. Fishcer, M. Perez-Mayo, D. Ransby, \& T.C. Jennerjahnn. 2019. Variability in the organic carbon stocks, sources, and accumulation rates of Indonesian mangrove ecosystems. Estuarine Coastal and Shelf Sci., 218: 310-323. https://doi.org/10.1016/j.ecss.2018.12 .007

Lee, S.Y., J.H. Primavera, F. DahdouhGuebas, K. McKee, J.O. Bosire, S. Cannicci, K. Diele, F. Fromard, N. Koedam, C. Marchand, I. Mendelssohn, N. Mukherjee, \& Record S. 2014. Ecological role and services of tropical mangrove ecosystems: a reassessment. Global Ecol. Biogeography, 23(7): 726-743. https://doi.org/10.1111/geb.12155

Lubis, A.A., B. Aliyanta, \& Y. Menry. 2007. Estimation of sediment accumulation rate in Jakarta Bay Using Natural Radionuclide Unsupported $210 \mathrm{~Pb}$. Indo J. Chem., 7(3): 309-313. https://doi.org/10.22146/ijc. 21674

Mahmood, H., K. Misri, B.J. Sidik, \& O. Saberi. 2005. Sediment accretion in a protected mangrove forests of Kuala 
Selangor, Malaysia. Pakistan J. Biol Sci., 8(1): 149-151. https://doi.org/10.3923/pjbs.2005.149 .151

Marchio, D.A., M. Savarese, B. Bovard, \& W.J. Mitsch. 2016. Carbon sequestration and sedimentation in mangrove swamps influenced by hydrogeomorphic conditions and urbanization in Southwest Florida. Forests, 7(6): 116(1-18). https://doi.org/10.3390/f7060116

Mukhlisi, K. \& Sidiyasa. 2014. Structure and composition of mangrove species in Berau Mangrove Information Centre (PIM), Kalimantan Timur. Indonesian for Rehabil J., 2(1): 25-37.

Murdiyarso, D., D. Donato, J.B. Kauffman, S. Kurnianto, M. Stidham, \& M. Kannien. 2009. Carbon storage in mangrove and peatland ecosystems. Working paper 48 , CIFOR. Bogor. 35 p.

Paputungan, M.S., A.F. Koropitan, T. Prartono, \& A.A. Lubis. 2016. Profil akumulasi sedimen di area restorasi mangrove Teluk Lembar Pulau Lombok. J. Ilmu dan Teknologi Kelautan Tropis, 9(1): 301-313. https://doi.org/10.29244/jitkt.v9i1.179 43

Sanchez-Cabeza, J.A., P. Masque, I. AniRagolta, J. Merino, M. Frignani, F. Alvisi, A. Palanques, \& P. Puig. 1999. Sediment accumulation rates in the Southern Barcelona continental margin (NW Mediterranean Sea) derived from $210 \mathrm{~Pb}$ and $137 \mathrm{Cs}$ chronology. Prog. Oceanogr., 44: 313-332. https://doi.org/10.1016/S00796611(99)00031-2
Sanders, J.C., J.M. Smoak, A.S. Naidu, L.M. Sanders, \& S.R. Patchineelam. 2010. Organic carbon burial in mangrove forest, margin and intertidal mud flat. Estuarine Coast Shelf Sci., 90: 168172. http://doi.org/10.1016/j.ecss.2010.08. 013

Smoak, J.M., J.L. Breithaupt, T.J. Smith III., \& C.J. Sanders. 2012. Sediment accretion and organic carbon burial relative to sea-level rise and storm events in two mangrove forests in Everglades National Park. Catena, 104: 58-66.

https://doi.org/10.1016/j.catena.2012. 10.009

Szmytkiewicz, A. \& T. Zaleswska. 2014. Sediment deposition and accumulation rates determined by sediment trap and $210 \mathrm{~Pb}$ isotope methods in the outer Puck Bay (Baltic Sea). Oceanologia, 56(1): 85-106. https://doi.org/10.5697/oc.56-1.085

Willard, D.A. \& C.W. Holmes. 1997. Pollen and geochronological data from south Florida: Taylor Creek Site 2. U.S. Geological Survey Open-file Report 97-35, $28 \mathrm{p}$.

Witasari, Y. 2015. Radioisotope Pb-210 untuk studi geoakrenologi sedimen di dasar laut. Oseana. 40(1): 1-9. http://oseanografi.lipi.go.id/dokumen/ os_xl_1_2015-1.pdf

Wolanski, E. 1995. Transport of sediment in mangrove swamps. Hydrobiologia, 295: 31-42. https://doi.org/10.1007/BF00029108

Received : 20 January 2020

Reviewed : 15 March 2020

Accepted : 13 July 2020 